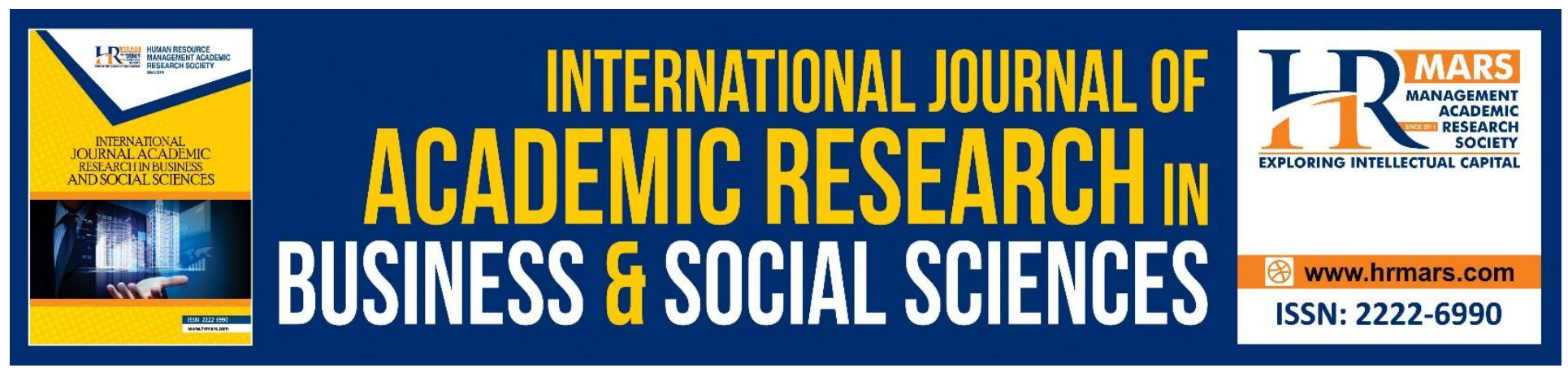

\title{
Science Teachers' Readiness in Implementing Authentic Learning Approach in Teaching and Learning
}

\section{Vijaya Letchumy Baskaran, Norazilawati Abdullah}

To Link this Article: http://dx.doi.org/10.6007/IJARBSS/v10-i8/7504

DOI:10.6007/IJARBSS/v10-i8/7504

Received: 02 May 2020, Revised: 04 June 2020, Accepted: 11 July 2020

Published Online: 18 August 2020

In-Text Citation: (Baskaran \& Abdullah, 2020)

To Cite this Article: Baskaran, V. L., \& Abdullah, N. (2020). Science Teachers' Readiness in Implementing Authentic Learning Approach in Teaching and Learning. International Journal of Academic Research in Business and Social Sciences, 10(8), 93-107.

Copyright: (C) 2020 The Author(s)

Published by Human Resource Management Academic Research Society (www.hrmars.com)

This article is published under the Creative Commons Attribution (CC BY 4.0) license. Anyone may reproduce, distribute, translate and create derivative works of this article (for both commercial and non-commercial purposes), subject to full attribution to the original publication and authors. The full terms of this license may be seen

at: http://creativecommons.org/licences/by/4.0/legalcode

Vol. 10, No. 8, 2020, Pg. 93 - 107

http://hrmars.com/index.php/pages/detail/IJARBSS

JOURNAL HOMEPAGE

Full Terms \& Conditions of access and use can be found at http://hrmars.com/index.php/pages/detail/publication-ethics 


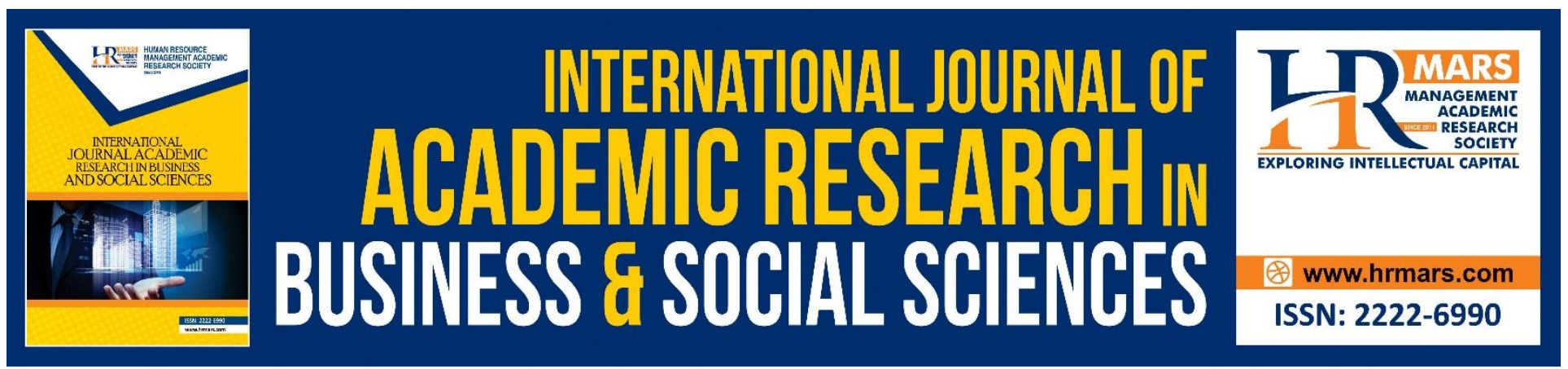

\title{
Science Teachers' Readiness in Implementing Authentic Learning Approach in Teaching and Learning
}

\author{
Vijaya Letchumy Baskaran, Norazilawati Abdullah \\ Faculty of Human Development, Sultan Idris Education University, ${ }^{2}$ National Child Development \\ Research Centre, Sultan Idris Education University \\ Email: nora@fpm.upsi.edu.my
}

\begin{abstract}
The purpose of this study was to identify Science teachers' readiness in implementing authentic learning approach while teaching Science. Teachers' readiness in this study was measured in terms of knowledge, skills, attitude and interest. Research samples consisted 110 primary school Science teachers from the district of Manjung. The design of the study was quantitative in nature employing the survey method by a questionnaire. This questionnaire used 5 points Likert Scale with strongly disagree to strongly agree. The questionnaire was divided into five sections a) respondents' information b) readiness in terms of knowledge c) readiness in terms of skills d) readiness in terms of attitude e) readiness in terms of interest. Data were analyzed using descriptive statistics of mean, frequency, percentage and standard deviation. Findings revealed that teachers have high mean value in readiness in terms of knowledge, attitude and. But teachers' readiness in terms of skills have recorded a moderate. Although teachers are ready in terms of knowledge, attitude and interest to carry out authentic learning approach while teaching Science they seem lacking in skills to fully implement authentic learning approach.
\end{abstract}

Keywords: Knowledge, Skills, Attitude, Skills, Authentic Learning.

\section{Introduction}

The Science education taught in schools must be able to reflect Science in the real world. Scientific concepts must be made relevant to students so that they become more accessible and interesting. Involving real life examples and hands-on learning will foster a deeper understanding of any scientific concepts taught.

Science education at schools must be meaningful for the students. Teachers must be able to reform initiatives by reconceptualizing the purpose of Science education by transforming them in helping the students to become enthusiastic lifelong learners. The Science lessons at school if carried out by implementing authentic learning approach will be able to stimulate experiences that will allow learners to derive understanding in the contexts learnt. Authentic learning environment will be able 
to establish a sense of personal control over what and how the learners learn. Teachers are considered successful when they are able to support the students' independent learning when the sense of personal control is established by the students themselves.

Teachers now must be able to acknowledge that they are not only instructors but also facilitators of learning. They are responsible in shaping the culture of their classroom. Teachers must always think of ways to promote creativity, critical thinking, collaboration and communication into the classroom. Teachers must be able to create an environment where students learn how to be adaptable, analytical and resourceful in order to succeed in a global environment.

Stanculescu (2013) have stated that students will be seen motivated when teachers are able to deliver lessons that are accurate, timely, stimulating and pertinent to their current and future needs. Students are often seen excited to learn something that is personal to their life and constantly expecting the teachers to implement a learning environment that can mirror the students' real-life, accessible, safe, positive, personalized as much as possible and empowering. When students are able to look beyond the scientific facts and able to see a practical application of it, it makes Science less daunting and provides an exciting avenue for explanations of their world. Science education is one of the best ways for teachers to develop creative minds.

The traditional teaching method is clearly unable to deliver knowledge that will enable the students to perform in their real-life experiences, where they need skills in solving complex problems. The knowledge taught are often without familiarity with the environment that the learners will be engaging with (Hui \& Koplin, 2011). Students are often seen failed to transfer the learnt knowledge into real life situations. These failures can be overcome if teachers are able to implement Authentic Learning approach in classrooms.

In this study, it has been suggested that Authentic Learning Model by Herrington, Oliver and Reeves (2010) is the best model to achieve the goal of teaching Science in an authentic learning environment. The models have proposed few guidelines for teachers to design authentic learning environments in schools. Although there are nine characteristics of authentic learning suggested for e learning activities, it can be equally well applied to authentic learning environments. However, it is not mandatory that all authentic learning approach should adhere to the nine characteristics. (Nikitina, 2011). An authentic learning approach offers an alternative instructional model and implementation of complex and realistic learning tasks (Herrington, Reeves \& Oliver, 2014)

Learning science authentically is an approach where teachers teach Science by aligning the lessons closely with how scientists do their work and it is different from traditional school science laboratory exercises. Authentic learning is a type of learning that is designed to connect what learners are taught in school to real world issues, problems and applications. Therefore, this study is being carried out to identify Science teachers' readiness in implementing authentic learning approach while teaching Science.

\section{Research Objectives}

This study is being carried out to identify the level of readiness among the primary school Science teachers in implementing Authentic Learning approach in Science education. Specifically, the research objectives are:

- Identifying the readiness level of Science teachers in term of knowledge in implementing Authentic Learning approach. 
INTERNATIONAL JOURNAL OF ACADEMIC RESEARCH IN BUSINESS AND SOCIAL SCIENCES Vol. 10, No. 8, 2020, E-ISSN: 2222-6990 @ 2020 HRMARS

- Identifying the readiness level of Science teachers in term of skills in implementing Authentic Learning approach.

- Identifying the readiness level of Science teachers in term of attitude in implementing Authentic Learning approach.

- Identifying the readiness level of Science teachers in terms of interest in implementing Authentic Learning approach.

\section{Literature Review}

The world is now rapidly changing with technological breakthroughs, mind blowing scientific discoveries and innovative inventions. The sudden growth and achievement that are happening around us also contributes to challenges that we need to tackle, such as climate change, increasing globalisation and big data. The process of overcoming these issues requires us to possess the right skills. We need citizens who are innovative and able to think creatively in solving those problems. How are we going to mould our students to be citizens that could do all that?

Before the world was filled with these technological and scientific breakthroughs, most workforce just required technical skills, such as knowing a specific trade or it would be adequate for a person to just have a specialised knowledge on something. At that time, the education system was doing well in preparing students with specialised knowledge, with a rigid, textbook driven curriculum that merely focused on memorising facts and working in isolation.

But now, all that became irrelevant. In this information age, industries are being replaced by automation that requires different types of skills. According to the World Economic Forum (2020) report, there is a huge gap in between the skills people learn and the skills that is needed now. The traditional method of teaching is struggling to equip these students with the knowledge and skills that they need to thrive.

Currently, teachers need to adopt the $21^{\text {st }}$ century education to produce $21^{\text {st }}$ century learners because they are the future workforce. These students have to be independent thinkers, problem solvers and decision makers (Silva, 2009). Therefore, $21^{\text {st }}$ century learners require $21^{\text {st }}$ century skills. Students need to be equipped with required 21st century skills and competencies in order for them to face the challenges of the future (Yoke, 2018).

The best way for them to obtain those skills are through science education. There is a unique relationship between $21^{\text {st }}$ century skills and science education. Science education has the ability to develop critical thinking skills, problem solving and digital literacy, and at the same time emphasizing the understanding of content knowledge and student engagement.

But Science education in schools are still taught in the traditional method and heavily focused on spoon-feeding teaching content. Science is best taught when the concepts are made relevant to students, they become more accessible and interesting. Science education must reflect science in the real world. Real life examples and hands-on learning foster a deeper understanding of scientific concepts. Science is best taught authentically.

Science is the best way to promote $21^{\text {st }}$ century skills. But how do teachers teach Science education in school to promote $21^{\text {st }}$ Century skills? Teaching and applying real-life examples and hands-on learning to foster a deeper understanding of scientific concepts can be carried out through Authentic Learning approach.

Authentic learning is a process where pedagogical approaches are used to empower students to collaborate with one another and together with their teachers to solve real world complex 
problems. Authentic learning is referring to a wide variety of educational and instructional techniques focused on connecting what our students are taught in school to real-world issues, problems and applications. Students will be more interested if they are motivated to learn new concepts and skills and better prepared to succeed in college, careers, and adulthood if what they are learning mirrors real-life contexts and also equips them with practical and also useful skills. It must address the topics that are relevant and applicable to their lives outside the school.

Authentic learning involves connection building. It cuts across disciplines and together bring students into a meaningful contact with the future employers, customers, clients and colleagues who will have greatest stake in their success. The notion of authenticity in education has been extensively discussed and analysed through empirical and theoretical works. Authentic learning is able to stimulate real life pedagogical practice, promote problem-based learning, collaborative learning and personal reflection on learning. Implementing authentic learning instructional strategies will provide students with opportunities to engage with content, pedagogy and meaningful student-centred learning.

According to Behizadeh and Fink (2015), authenticity has greatly supported as students' perception towards tasks are connected to their lives. Authentic learning typically focuses on realworld, complex problems and their solutions, using role-playing exercises, problem-based activities, case studies and participation in virtual communities of practice.

Teaching Science authentically will allow students to connect what they have learned at school to their daily lives. When students are seen able to use real tools with real purposes and come up with tangible products, learning is considered highly effective. Learners are able to retain the new concepts longer. The newly learnt concepts are modified and arranged and thus new links are created during that process (Vallori, 2014). This at the end simplifies the newly learnt concept to be assimilated by the students.

Authentic learning is an instructional approach that blends the theories learnt in the classroom with the students' daily lives and prior knowledge. Thus, it is an approach that places students at the real-world experiences. Learning will become more personal, and with the exposure to new contexts that need to be explored, students can be seen developing academic and problem-solving skills that will prepare them for the upcoming future.

In our future workforce, we need students who really understand the world and how it works. It begins in the classroom, where it can be connected to the real-world scenarios through a different method of teaching. Bridging the knowledge learnt in the classroom to the outside world by implementing authentic learning approach will equip the students with the tools that they need to meet the demands of the future.

Even though there are many researches that have been carried out to identify the impact of teaching Science through an authentic learning environment, there are fewer research that has been carried out in identifying teachers' readiness level in implementing them. For example, a research carried out by (Mariani et al., 2014) showed that lecturers in Sungai Petani Vocational College are seen very knowledgeable in $21^{\text {st }}$ Century education but their teaching strategies to implement those skills among their students can be improved. This is due to the fact that these lectures are still implementing teacher centered teaching method by giving notes and lectures.

According to Barber and Mourshed (2007), in How the World's Best Performing Systems Come Out on Top, it is stated that quality of education is directly dependent to the teachers' quality. Teachers' quality must be improved in order to produce a world class education system for 
INTERNATIONAL JOURNAL OF ACADEMIC RESEARCH IN BUSINESS AND SOCIAL SCIENCES Vol. 10, No. 8, 2020, E-ISSN: 2222-6990 @ 2020 HRMARS

Malaysia.Related to that, this study has been carried out to identify teachers' readiness in implementing authentic learning approach in the classrooms. The responsibilities of preparing students for the work and situation that have not been created yet is solely depends on the teachers.

Authentic learning has become as much social as cognitive, as much concrete as abstract, and becomes intertwined with judgment and exploration, just as it is in an actual workplace. Science education also if taught correctly is able to promote teamwork and communication, skills needed for them to thrive in the workforce of the future. The reality is, Scientists don't work in isolation and just regurgitate facts. They collaborate, and constantly developing new ideas. Thus, this study is being carried out to identify the readiness level of primary school Science teachers in teaching Science through authentic learning approach.

\section{Research Methodology}

This research is a quantitative research that uses survey method. This research has been conducted in the district of Manjung, Perak. The research sample is chosen through stratified sampling method. Data obtained by the Education Department of the Manjung district shows that there are 2260 primary school teachers in this district. Out of those teachers, there are 321 Science teachers from all three streams of school. Thus, a multiple- staged stratified random sampling procedure was used in this study because of it highly recommended efficiency (Sekaran, 2000). A total of 33\% of each stratum of the population was chosen randomly for the survey.

The questionnaire will be distributed to 106 Science teachers in Manjung. The table below shows the number of teachers for each stream by using a simple sampling method.

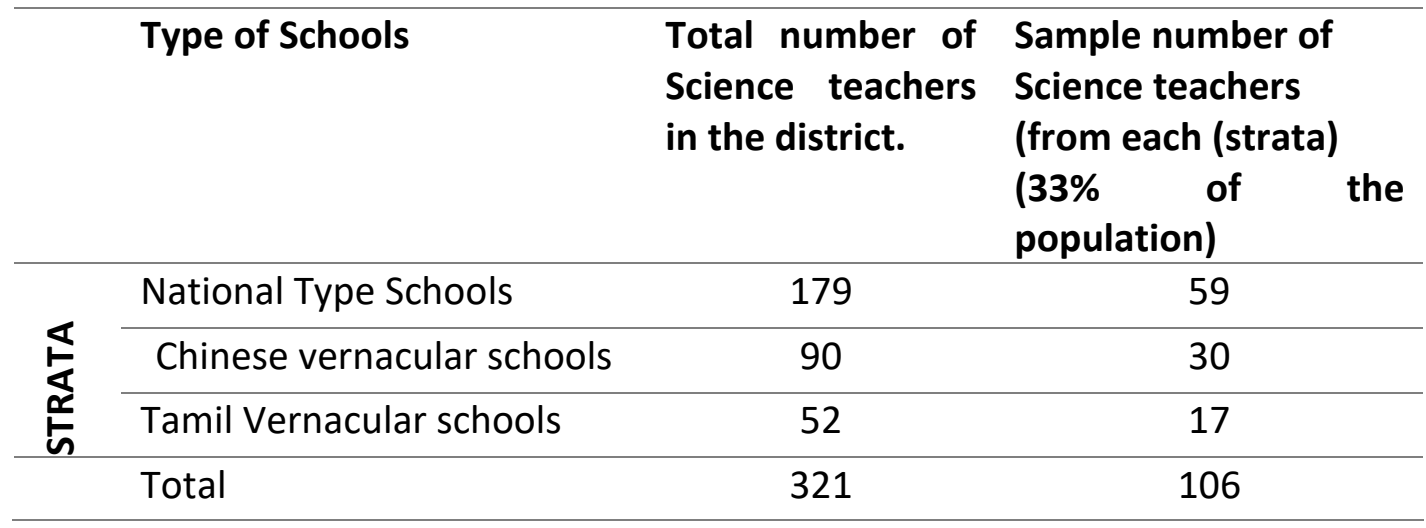

Table 1: Research samples.

Science teachers have been chosen in this study because Science education is one of the most important subjects in school since that provides life-long skills which allow students to generate ideas, and most importantly prepare the students for the future. Science and technological literacy, critical thinking and problem-solving skills obtained through learning Science will equip students with skills that they need to succeed in school and their future.

The research instrument was adapted and modified from the research conducted by Rumaizah (2014) that consist two main parts, which are Part A and Part B. Part A discusses about respondents' gender, age, ethnic, teaching experiences, academic status, location, teaching options and courses attended by them. Meanwhile, in Part B, respondents have to choose from 5 option on 
INTERNATIONAL JOURNAL OF ACADEMIC RESEARCH IN BUSINESS AND SOCIAL SCIENCES Vol. 10, No. 8, 2020, E-ISSN: 2222-6990 @ 2020 HRMARS

the Likert Scale that is stated on the questionnaire. The options are (5) Strongly Agree, (4) Agree, (3) Unsure, (2) Disagree (1) Strongly Disagree. Part B consist of 4 main domains that consist of teachers' readiness in the aspect of knowledge (10 items), teachers' readiness in the aspect of skill (6 items), teachers' readiness in the aspect of attitude (10 items), teachers' readiness in the aspect of interest (8 items).

A pilot study will be carried out among 20 primary school Science teachers. The pilot study is carried out to identify the issues that will be faced by the respondents regarding the understanding and item interpretation. Those 20 teachers that are involved in the pilot study will not be involved in the main research. The construct analysis is important to ensure that the chosen constructs are suitable to be used as research instrument. The pilot study is also carried out to obtain the reliability of the instruments to identify the internal consistency of each item that is involved.

Table 2: Cronbach's Alpha value of the variables involved.

\begin{tabular}{ccc}
\hline Variables & Nu of items & Cronbach's Alpha Value \\
\hline Knowledge & 10 & 0.946 \\
\hline Skills & 6 & 0.931 \\
\hline Attitude & 10 & 0.919 \\
\hline Interest & 8 & 0.912 \\
\hline
\end{tabular}

Data analysis will be carried out using Statistical Package for Social Science (SPSS) Version 25.0. Descriptive statistic and inferential statistics will be used to describe the variables involved. Descriptive statistics uses indicators such as mean, standard deviation, median, mod, normal curve and $Z$ score to state the characteristics of the variables in a study. (Chua Yan, 2009). It can describe the data obtained in the forms of charts, graphs and also tables. This is the best way to simplify the big amount of data obtained from the research itself to be understood well. (Azizi et al, 2006).

Descriptive analysis and percentages are used to determine teachers' readiness level of practicing Authentic Learning approach at schools in the aspect of knowledge, skills, attitude and interest. The frequency and percentages are used to describe the respondents' demographical features by referring to their gender, age, ethnic, experiences and teaching options.

Table 3 describes the mean according to the score and interpretation of each item that is being tested. Mean score of this study has been categorized into three groups. The mean score of 0.00 to 2.33 explains minimal level. Mean score of 2.34 to 3.66 shows intermediate level and higher level is represented by a mean score of 3.67 to 5.00 . (Dyer, 2006).

Table 3: The mean values and its interpretation.

\begin{tabular}{cc}
\hline Mean Score & Mean Interpretation \\
\hline $\mathbf{0 . 0 0}$ to 2.33 & Low \\
\hline $\mathbf{2 . 3 4}$ to 3.66 & Intermediate \\
\hline $\mathbf{3 . 6 7}$ to 5.00 & High \\
\hline
\end{tabular}


INTERNATIONAL JOURNAL OF ACADEMIC RESEARCH IN BUSINESS AND SOCIAL SCIENCES Vol. 10, No. 8, 2020, E-ISSN: 2222-6990 @ 2020 HRMARS

Table 4: Research questions and statistical analysis used.

\begin{tabular}{lll}
\hline & Research Questions & Statistical Analysis \\
\hline $\mathbf{1}$ & $\begin{array}{l}\text { What is the readiness level of Science teachers } \\
\text { in term of knowledge in implementing }\end{array}$ & Descriptive \\
& $\begin{array}{l}\text { Authentic Learning approach? } \\
\text { What is the readiness level of Science teachers } \\
\text { in term of skills in implementing Authentic } \\
\text { Learning approach? }\end{array}$ & Descriptive \\
\hline $\mathbf{3} \quad \begin{array}{l}\text { What is the readiness level of Science teachers } \\
\text { in term of interests in implementing Authentic } \\
\text { Learning approach? }\end{array}$ & Descriptive \\
\hline $\mathbf{4} \quad \begin{array}{l}\text { What is the readiness level of Science teachers } \\
\text { in terms of attitude in implementing Authentic } \\
\text { Learning approach? }\end{array}$ & Descriptive \\
\hline
\end{tabular}

\section{Findings}

The questionnaire was distributed in two ways. First 60 questionnaires were distributed to schools according to the streaming. The questionnaires were also distributed through Google Form to the Head Panel of the Science Subjects in schools. It was done through this way in order for it to be distributed among the Science teachers in their respective schools. A total of 110 responses were recorded through both ways.

Seven demographical features were recorded through the research instrument. They are respondents' gender, age, ethnicity, teaching experiences, location of the school, academic qualifications, and number of portfolios hold by the educator. Based on the findings, it has been recorded that there 12 male teachers (10.9\%) and $98(89.1 \%)$ of the respondents are female. There are also 6 (5.45\%) teachers who are from 20-30 years old age group; 44 (40\%) teachers from 30-40 years old age group; 45 (40.9\%) from 40-50 years old age group and there are 15 (13.6\%) 50 years old and above. From these respondents 39 (35.5\%) of these teachers are Malays, 43 (39.1\%) of them are Chinese and 28 (25.5\%) are Indian teachers. Based on the respondents' teaching experiences, $6(5.5 \%)$ of them have less than 5 years of experience, $13(11.8 \%)$ of them have $5-10$ tears of teaching experience, 34 (30.9\%) of them have $10-15$ years of teaching experience and $57(51.8 \%)$ of them have more than 16 years of teaching experience. Based on the findings, 72 (65.5\%) of the respondents come from schools that is situated in the suburban area of the district and 38 of them comes from town area school. Table 5 shows the summary of the demographical characteristics of the respondents 
INTERNATIONAL JOURNAL OF ACADEMIC RESEARCH IN BUSINESS AND SOCIAL SCIENCES Vol. 10, No. 8, 2020, E-ISSN: 2222-6990 @ 2020 HRMARS

\begin{tabular}{|c|c|c|c|}
\hline Demography & Characteristics & Number & Percentage (\%) \\
\hline \multirow[t]{2}{*}{ Gender } & Male & 12 & $10.9 \%$ \\
\hline & Female & 98 & $89.1 \%$ \\
\hline \multirow[t]{4}{*}{ Age } & $20-30$ years old & 6 & $5.50 \%$ \\
\hline & $30-40$ years old & 44 & $40.0 \%$ \\
\hline & $40-50$ years old & 45 & $40.9 \%$ \\
\hline & 50 years old above & 15 & $13.6 \%$ \\
\hline \multirow[t]{3}{*}{ Ethnic } & Malay & 39 & $35.5 \%$ \\
\hline & Chinese & 43 & $39.1 \%$ \\
\hline & Indian & 28 & $25.5 \%$ \\
\hline \multirow{4}{*}{$\begin{array}{l}\text { Teaching } \\
\text { Experiences }\end{array}$} & $0-5$ years & 6 & $5.5 \%$ \\
\hline & $5-10$ years & 13 & $11.8 \%$ \\
\hline & $10-15$ yeas & 34 & $30.9 \%$ \\
\hline & 16 years and above & 57 & $51.8 \%$ \\
\hline \multirow[t]{2}{*}{ School Location } & Suburban area & 72 & $65.5 \%$ \\
\hline & Town area & 38 & $34.5 \%$ \\
\hline \multirow{4}{*}{$\begin{array}{l}\text { Academic } \\
\text { Qualifications }\end{array}$} & Diploma & 10 & $19.1 \%$ \\
\hline & First Degree & 89 & $80.9 \%$ \\
\hline & Masters' Degree & 11 & $1.0 \%$ \\
\hline & Doctorate & 0 & 0 \\
\hline
\end{tabular}

Table 5: Summary of demographical characteristics of the respondents.

Table 6 below shows the findings for the teachers' readiness level in terms of knowledge, skill, interest and attitude. The highest score $(M=3.9664, S D=0.80766)$ was recorded for the dimension of attitude and the lowest score $(M=3.6257, S D=0.67555)$ for skills dimension. The second highest dimension was recorded by teachers' interest with the score of $(M=3.8136, S D=0.64254)$. The knowledge dimension's score is $(M=3.7782, S D=0.56385)$

Table 6: Level of teachers' readiness in implementing authentic learning approach.

\begin{tabular}{llll}
\hline Dimension & $\mathbf{N}$ & Mean & SD \\
\hline Knowledge & 110 & 3.7782 & 0.56385 \\
\hline Skills & 110 & 3.6257 & 0.67555 \\
\hline Attitude & 110 & 3.9664 & 0.80766 \\
\hline Interest & 110 & 3.8136 & 0.64254 \\
\hline
\end{tabular}


INTERNATIONAL JOURNAL OF ACADEMIC RESEARCH IN BUSINESS AND SOCIAL SCIENCES Vol. 10, No. 8, 2020, E-ISSN: 2222-6990 @ 2020 HRMARS

\section{Research Question 1: What is the level of readiness among Science teachers in term of knowledge to implement Authentic Learning approach?}

Table 7: Item mean for Teachers' Readiness Level in Terms of Knowledge

\begin{tabular}{|c|c|c|c|}
\hline \multicolumn{2}{|r|}{ Items on Teachers' Readiness Level in Terms of Knowledge } & \multirow{2}{*}{$\begin{array}{l}\text { Mean } \\
3.3909\end{array}$} & \multirow{2}{*}{$\begin{array}{l}\text { SD } \\
0.56007\end{array}$} \\
\hline P1 & $\begin{array}{l}\text { I have the knowledge to conduct Science lessons by } \\
\text { implementing an Authentic Learning approach. }\end{array}$ & & \\
\hline $\mathbf{P 2}$ & I am qualified to teach Science effectively. & 3.7727 & 0.67265 \\
\hline P3 & $\begin{array}{l}\text { I have expertise in every topic and item in the Science } \\
\text { syllabus. }\end{array}$ & 3.9273 & 0.57003 \\
\hline P4 & $\begin{array}{l}\text { I am able to deliver Science content knowledge in a way that } \\
\text { students able to use it as tools to solve real-world problems. }\end{array}$ & 3.8909 & 0.47594 \\
\hline P5 & $\begin{array}{l}\text { I am able to deliver Science content knowledge that ensures } \\
\text { students' mastery in the subject. }\end{array}$ & 3.8818 & 0.50196 \\
\hline P6 & $\begin{array}{l}\text { I am able to use a variety of instructional strategies to engage } \\
\text { the students in learning Science. }\end{array}$ & 3.8455 & 0.56156 \\
\hline P7 & $\begin{array}{l}\text { I am always ready to share my knowledge with other } \\
\text { teachers involved in Science education. }\end{array}$ & 3.7545 & 0.56156 \\
\hline P8 & $\begin{array}{l}\text { I am able to take into account learners' previous knowledge } \\
\text { to plan activities in the classroom. }\end{array}$ & 3.8636 & 0.62776 \\
\hline P9 & $\begin{array}{l}\text { I am able to create learning environments that meet the } \\
\text { standard/ curriculum. }\end{array}$ & 3.8 & 0.46531 \\
\hline \multirow[t]{2}{*}{ P10 } & $\begin{array}{l}\text { I have the knowledge to develop, administer, score, and } \\
\text { interpret the results of the assessment based on the Science } \\
\text { curriculum (DSKP). }\end{array}$ & 3.6545 & 0.64162 \\
\hline & & 3.7782 & 0.56385 \\
\hline
\end{tabular}

The level of teacher readiness in terms of knowledge have recorded $(M=3.7782, S D=0.56385)$. Table 7 above shows the items in this dimension and their recorded score. The highest score is P3 $(M=3.9273, S D=0.57003)$, where teachers agree that they have expertise in every topic and item in the Science syllabus. The item that the lowest score is $P 1(M=3.3909, S D=0.56007)$ which discusses on the teachers' knowledge to conduct Science lessons by implementing Authentic Learning approach. Higher mean score has been recorded by items P2 ( $M=3.7727, S D=0.67265), P 4(M=$ $3.8909, \mathrm{SD}=0.47594), \mathrm{P} 5(\mathrm{M}=3.8818, \mathrm{SD}=0.50196), \mathrm{P} 6(3.8455, \mathrm{SD}=0.56156), \mathrm{P} 7(\mathrm{M}=3.7545, \mathrm{SD}$ $=0.56156), P 8(M=3.8636, S D=0.62776)$ and $P 9(M=3.8, S D=0.46531)$ while $P 10$ have scored and average mean value $(M=3.6545, S D=0.64162)$. The result shows that teachers in the district of Manjung have high level of readiness in terms of knowledge to implement authentic learning approach in their teaching and learning activities 
INTERNATIONAL JOURNAL OF ACADEMIC RESEARCH IN BUSINESS AND SOCIAL SCIENCES Vol. 10, No. 8, 2020, E-ISSN: 2222-6990 @ 2020 HRMARS

\section{Research question 2: What is the readiness level of Science teachers in term of skills in implementing Authentic Learning approach?}

The level of teacher readiness in terms of skills have recorded $(M=3.6257, S D=0.0 .67555)$. Table 8 below shows the items in this dimension and their recorded score. The highest score is $\mathrm{K} 2$ ( $\mathrm{M}=$ $3.7909, \mathrm{SD}=0.67858$ ), where teachers are able to encourage active and ensure equitable learner participation during Science lessons. Meanwhile, the items that have the lowest score is $\mathrm{K} 1(\mathrm{M}=$ 3.3545, SD $=0.64376$ ) which discusses on teachers' skills to implement an Authentic Learning approach to teach Science. Other higher scores are recorded by K4 $(M=3.7272, S D=0.6194)$. Items K3 $(M=3.6545, S D=0.72234), K 5(M=3.6545, S D=0.64162), K 6(M=3.5727, S D=0.74758)$ have scored average mean value. Findings show that the readiness level of the primary school teachers in Manjung district in terms of skills is at a moderate level.

Table 8: Item mean for Teachers' Readiness Level in Terms of Skills

\begin{tabular}{|c|c|c|c|}
\hline \multicolumn{2}{|r|}{ Items on Teachers' Readiness Level in Terms of Skills } & \multirow{2}{*}{$\begin{array}{l}\text { Mean } \\
3.3545\end{array}$} & \multirow{2}{*}{$\begin{array}{l}\text { SD } \\
0.64376\end{array}$} \\
\hline K1 & $\begin{array}{l}\text { I have the skills to implement an Authentic } \\
\text { Learning approach to teach Science. }\end{array}$ & & \\
\hline K2 & $\begin{array}{l}\text { I am able to encourage active and ensure } \\
\text { equitable learner participation during Science } \\
\text { lessons }\end{array}$ & 3.7909 & 0.67858 \\
\hline K3 & $\begin{array}{l}\text { I am able to organize activities into logical stages } \\
\text { to meet the objectives of the lesson. }\end{array}$ & 3.6545 & 0.72234 \\
\hline K4 & $\begin{array}{l}\text { I am always ready to share my skills with other } \\
\text { teachers involved in Science education. }\end{array}$ & 3.7273 & 0.6194 \\
\hline K5 & $\begin{array}{l}\text { I am able to create conditions that require } \\
\text { learners' adaptability. }\end{array}$ & 3.6545 & 0.64162 \\
\hline \multirow[t]{2}{*}{ K6 } & $\begin{array}{l}\text { I have the skill to develop, administer, score and } \\
\text { interpret the results of assessment based on the } \\
\text { Science curriculum (DSKP). }\end{array}$ & 3.5727 & 0.74758 \\
\hline & & 3.6257 & 0.675547 \\
\hline
\end{tabular}

\section{Research Question 3: What is the readiness level of Science teachers in term of attitude in implementing Authentic Learning approach?}

The level of teacher readiness in terms of attitude have recorded $(M=3.9664, S D=0.80766)$. Table 9 below shows the items in this dimension and their recorded score. Findings show that the readiness level of the primary school teachers in Manjung district in terms of attitude is at high level.

The highest score is S2 $(M=4.2909, S D=0.7338)$, where teachers are able to be confident in teaching Science authentically Meanwhile, the item that has the lowest score is S6 ( $M=3.6364$ SD = 1.3459) which discusses on teachers' understanding of learners' different abilities, learning rates and styles. Other items that have recorded high scores are S1(M $=4.2091, \mathrm{SD}=0.8138)$ S3 (M $=3.8545$, $S D=0.7522)$, S4 ( $M=4.0545, S D=0.8109), S 7(M=4.0273, S D=0.7098), S 8(M=4.154, S D=0.7192)$ S9 $(M=3.818, S D=0.706), S 10(M=3.782, S D=0.655)$. 
INTERNATIONAL JOURNAL OF ACADEMIC RESEARCH IN BUSINESS AND SOCIAL SCIENCES Vol. 10, No. 8, 2020, E-ISSN: 2222-6990 @ 2020 HRMARS

\begin{tabular}{|c|c|c|c|}
\hline \multicolumn{2}{|r|}{ Items on Teachers' Readiness Level in Terms of Attitude } & \multirow{2}{*}{$\begin{array}{l}\text { Mean } \\
4.2091\end{array}$} & \multirow{2}{*}{$\begin{array}{l}\text { SD } \\
0.8138\end{array}$} \\
\hline S1 & $\begin{array}{l}\text { I am comfortable teaching Science by implementing an } \\
\text { Authentic Learning approach. }\end{array}$ & & \\
\hline S2 & I am more confident in teaching Science authentically. & 4.2909 & 0.7338 \\
\hline S3 & $\begin{array}{l}\text { I am required to make preparations before teaching to ensure } \\
\text { learning is carried out authentically. }\end{array}$ & 3.8545 & 0.7522 \\
\hline S4 & $\begin{array}{l}\text { I am able to use instructional strategies that motivate and } \\
\text { engage learners. }\end{array}$ & 4.0545 & 0.8109 \\
\hline S5 & $\begin{array}{l}\text { I have the ability to understand the structure of the Science } \\
\text { curriculum in which authentic learning will take place. }\end{array}$ & 3.8364 & 0.8298 \\
\hline S6 & $\begin{array}{l}\text { I am able to understand learners' different abilities, learning } \\
\text { rates and styles. }\end{array}$ & 3.6364 & 1.3459 \\
\hline S7 & $\begin{array}{l}\text { I am able to carry out small scale research activities in my } \\
\text { classes to become better informed of the instructional } \\
\text { strategies. }\end{array}$ & 4.0273 & 0.7098 \\
\hline S8 & $\begin{array}{l}\text { I am ready to participate in courses that will help me to teach } \\
\text { Science authentically. }\end{array}$ & 4.1545 & 0.7192 \\
\hline S9 & $\begin{array}{l}\text { Teaching Science through authentic learning approach is a } \\
\text { challenge for teachers. }\end{array}$ & 3.818 & 0.706 \\
\hline \multirow[t]{2}{*}{ S10 } & $\begin{array}{l}\text { I am constantly involved in meetings, briefings and activities } \\
\text { that is related to Science education. }\end{array}$ & 3.782 & 0.655 \\
\hline & & 3.9664 & 0.8077 \\
\hline
\end{tabular}

Table 9: Item mean for Teachers' Readiness Level in Terms of Attitude.

\section{Research question 4: What is the readiness level of Science teachers in terms of interest in implementing Authentic Learning approach?}

The level of teacher readiness in terms of interest have recorded $(M=3.8136, S D=0.64254)$ Table 10 below shows the items in this dimension and their recorded score Findings show that the readiness level of the primary school teachers in Manjung district in terms of interest is at a high level. The highest score is $\mathrm{M} 1(\mathrm{M}=3.9182, \mathrm{SD}=0.56067)$, where it shows that teachers are very interested in teaching Science. Meanwhile, the item that has the lowest score is $M 8(M=3.5455$ SD $=0.9049)$ where the item discusses on the interest of the teachers on teaching Science as a challenge for them. Other items that have recorded high scores are $M 2(M=3.9818, S D=0.55821) M 4(M=3.9091, S D=$ $0.58334), M 5(M=3.8545, S D=0.58790), M 6(M=3.8455, S D=0.6086), M 7(M=3.8636, S D=$ $0.69701)$. An average score has been recorded by $M 3(M=3.5909, S D=0.63960)$ 
INTERNATIONAL JOURNAL OF ACADEMIC RESEARCH IN BUSINESS AND SOCIAL SCIENCES Vol. 10, No. 8, 2020, E-ISSN: $2222-6990 \Subset 2020$ HRMARS

\begin{tabular}{|c|c|c|c|}
\hline \multicolumn{2}{|r|}{ Items on Teachers' Readiness Level in Terms of Interest } & \multirow{2}{*}{$\begin{array}{l}\text { Mean } \\
3.9182\end{array}$} & \multirow{2}{*}{$\begin{array}{l}\text { SD } \\
0.56067\end{array}$} \\
\hline M1 & I am very interested to teach Science. & & \\
\hline M2 & $\begin{array}{l}\text { I am very interested in teaching the Science subject } \\
\text { because Science education is important in enhancing } \\
21^{\text {st }} \text { Century Skills. }\end{array}$ & 3.9818 & 0.55821 \\
\hline M3 & $\begin{array}{l}\text { I volunteered to teach Science authentically to develop } \\
21^{\text {st }} \text { Century skills among the students. }\end{array}$ & 3.5909 & 0.63960 \\
\hline M4 & $\begin{array}{l}\text { I am interested in teaching Science because of the } \\
\text { experience that I have. }\end{array}$ & 3.9091 & 0.58334 \\
\hline M5 & $\begin{array}{l}\text { I am interested to teach Science because } 21^{\text {st }} \text { century } \\
\text { learning has become a priority in my school. }\end{array}$ & 3.8545 & 0.58790 \\
\hline M6 & $\begin{array}{l}\text { I am interested to teach Science because I was trained } \\
\text { to teach Science in the Institute. }\end{array}$ & 3.8455 & 0.60860 \\
\hline M7 & $\begin{array}{l}\text { I am interested to teach Science because I am able to } \\
\text { use different instructional strategies that suit learners' } \\
\text { needs in learning. }\end{array}$ & 3.8636 & 0.69701 \\
\hline \multirow[t]{2}{*}{ M8 } & $\begin{array}{l}\text { I am interested in teaching Science because it is a } \\
\text { challenge for me. }\end{array}$ & 3.5455 & 0.90499 \\
\hline & & 3.8136 & 0.64254 \\
\hline
\end{tabular}

Table 10: Item mean for Teachers' Readiness Level in Terms of Interests

\section{Discussion and Conclusion}

Considering the grand mean value, teachers are seen ready to implement authentic learning approach in their classes although teacher's readiness in terms of skills is at a moderate level. Teachers are responsible to prepare and educate students for the unknown. Thus, learning should be able to provide students with tools to thrive in the $21^{\text {st }}$ century by helping them to develop critical and creative thinking and allowing the students to collaborate and communicate while solving problems and fostering resilience and at the same time have a growth mindset. All these can be achieved through authentic learning approach.

Authentic learning takes place when students are cognitively engaged in a meaningful and functional curriculum relevant to their lives. Since, authentic learning approach is still a novelty in Malaysia and its success is dependent on the competency of the teachers and their teaching readiness. This explains the findings of this research that concluded teachers' readiness in terms of skills are at a moderate level. Teachers clearly need profession development in improving their understanding. According to Carlgren (2013); Amran \& Rosli (2017), the level of teachers' understanding will influence how a teacher acts, makes decisions and apply teaching practice.

Authentic learning will provide students with more engaging, thought-provoking learning opportunities. Thus, this situation requires teachers to experiment with incorporating inquiry-based learning into their curriculum. Just by having an interest alone will not help in implementing this new model. Teachers are often seen lack in skills to conduct teaching through "learning by doing". Teachers can be seen struggling because they don't have adequate information, support and tools that are necessary to support this new model of teaching and learning. This is why, in this study, 
INTERNATIONAL JOURNAL OF ACADEMIC RESEARCH IN BUSINESS AND SOCIAL SCIENCES Vol. 10, No. 8, 2020, E-ISSN: 2222-6990 @ 2020 HRMARS

teachers' readiness to implement authentic learning approach in terms of skills are still at moderate level.

Teachers are considered to be the front liners who will be responsible to transmit knowledge, skills and values to the new generations (Dawi, 2006). Thus, their readiness is important to ensure successful implementation of authentic learning approach. Authentic learning approach will allow students to have the opportunity to engage in projects and activities that will require them to employ the knowledge taught to solve real world problems.

The implication of this study is identifying teachers' readiness in terms of knowledge, skill, attitude and interest in implementing authentic learning approach. Authentic learning approach is important in instilling $21^{\text {st }}$ learning skills among our students. $21^{\text {st }}$ century skills are important in moulding the students to be future ready. It would be difficult for teachers to foster these skills without any teaching and learning models that is specifically designed to understand the needs of these students.

Thus, by implementing authentic learning approach, especially in the Science subject will allow students to take part in complex, meaningful projects that require sustained engagement, collaboration and later will contribute to the development of an ambitious performance or product. The Science subject would be meaningful when it is taught authentically. Teaching Science authentically includes applying scientific knowledge in a manner that mirrors their daily lives and practices. This learning approach will allow the students to engage in realistic tasks using real-world resources and tools. Authentic learning approach will allow students to learn the scientific facts with intention by thinking and acting like professionals as they are given real problems to solve.

In an authentic learning environment, the tasks are ill-defined and complex. It is done this way to engage the learners to understand the conceptual change that is needed in learning Science. When teachers assign authentic task to students during their teaching and learning activities, students will be able to acquire and develop their knowledge ideally through successful completion of the task itself.

Teachers are always challenged in identifying the correct knowledge needed by the students that is worth learning. They have to identify the kind of teaching and learning activities that are needed to make the students life ready. Being in the $21^{\text {st }}$ century, requires teachers to help students to develop critical and creative thinking, collaboration and communication skills to solve problems and foster resilience. Implementing authenticity in teaching Science will create joy in learning Science. This will motivate them to explore the world around them by accepting different points of views and learning from mistakes.

From the study we know that teachers are ready to implement authentic learning approach in their respective classrooms. They must be provided with opportunities and support to develop their competency level. Thus, professional development and policy makers such as Pejabat Pendidikan Daerah (PPD), Jabatan Pelajaran Negeri (JPN) and KPM should be alert on this and at all times be supportive of the teachers.

\section{References}

Amran, N., \& Rosli, R. (2017). Teachers' Understanding in 21st Century Skills. Prosiding Persidangan Antarabangsa Sains Sosial \& Kemanusiaan.

Barber, M., and Mourshed, M. (2010) Shaping the future: How good education systems can become 
INTERNATIONAL JOURNAL OF ACADEMIC RESEARCH IN BUSINESS AND SOCIAL SCIENCES

Vol. 10, No. 8, 2020, E-ISSN: 2222-6990 @ 2020 HRMARS

great in the decade ahead: Report on the International Education Roundtable (7 July 2009, Singapore), Educational Studies, 3, 6-31.

Behizadeh, N., \& Fink, L. S. (2015). Engaging Students Through Authentic and Effective Literacy Instruction. Voices from the Middle, 23(1), 40-50.

Carlgren, T. (2013). Communication, Critical Thinking, Problem Solving: A Suggested Course for All High School Students in the 21st Century. Interchange. 44. 10.1007/s10780-013-9197-8.

Herrington, J., Reeves, T. C., \& Oliver, R. (2010). A guide to authentic e-learning. London: Routledge.

Herrington, J., Reeves, T. C., \& Oliver, R. (2014b). Authentic learning environments. In J. M. Spector et al. (Eds.), Handbook of research on educational communications and technology (pp. 401412). New York: Springer. doi: 10.1007/978-1-4614-3185-5_32.

Hui, F., \& Koplin, M. (2011). The Implementation of Authentic Activities for Learning: A Case Study in Finance Education. E-Journal of Business Education \& Scholarship of Teaching. 5, 59-72

Nikitina, L. (2011). Creating an authentic learning environment in the foreign language classroom. International Journal of Instruction, 4(1), 33-45.

Sekaran, U. (2000) Research Methods for Business: A Skill Business Approach. John Wiley \& Sons, New York.

Stanculescu, E. (2013). University Student's Fear of Success from The Perspective of Positive Psychology. Procedia-Social and Behavioral Science, 7 (8) Pp. 728-732.

Vallori, A. (2014). Meaningful Learning in Practice. Journal of Education and Human Development. $3 .$. WEF [World Economic Forum]. (2020). The Global Risks Report 2020. Retrieved from http://www3.weforum.org/docs/WEF_Global_Risk_Report_2020.pdf.

Yahaya, A., Hashim, S., Ramli, J., Boon, Y., Hamdan, A. R. (2006). Menguasai Penyelidikan dalam Pendidikan. Kuala Lumpur: PTS Professional Publishing Sdn. Bhd.

\section{Author Information}

Author

Vijaya Letchumy Baskaran, Faculty of Human Development, Sultan Idris Education University

Email: vijayaletchumy78@gmail.com

\section{Corresponding Author}

Norazilawati Abdullah

National Child Development Research Centre,

Sultan Idris Education University

Email: nora@fpm.upsi.edu.my 